\title{
Cantharellus amazonensis, a new species from Amazon
}

\author{
Wartchow $\mathbf{F}^{*}$, Santos $\mathrm{JC}^{2}$ and Fonseca $\mathrm{MDP}^{2}$ \\ ${ }^{1}$ Universidade Federal da Paraíba, Departamento de Departamento de Sistemática e Ecologia, CEP: 58051-970, João \\ Pessoa, PB, BRAZIL \\ ${ }^{2}$ Universidade Federal do Amazonas, Programa de Pós-graduação BIONORTE - Rede de Biodiversidade e \\ Biotecnologia da Amazônia Legal, CEP: 69077-000, Manaus, AM, Brazil
}

Wartchow F, Santos JC, Fonseca MDP 2012 - Cantharellus amazonensis, a new specis from Amazon. Mycosphere 3(4), 414-418, Doi 10.5943 /mycosphere/3/4/4

Cantharellus amazonensis is described as a new species from the Amazon. It is characterized by the contrasting red pileus with yellow folds and stipe, the basidiospores size and thin-walled pileipellis hyphae. A description, discussion, photograph and line drawings are provided.

Key words - Cantharellaceae - Cantharellales - Neotropic - taxonomy

\section{Article Information}

Received 30 May 2012

Accepted 3 July 2012

Published online 10 July 2012

*Corresponding author: Felipe Wartchow - e-mail - fwartchow@ yahoo.com.br

\section{Introduction}

Cantharellus Adans.: $\mathrm{Fr}$ is a conspicuous mycota element that forms ectomycorrhizal associations with canopy trees in Northern South America (Henkel et al. 2012, Wilson et al 2012). The first reports of the genus from Brazilian Amazon were of $C$. pusio Berk. (Berkeley 1856) and of C. cibarius Fr. (Berkeley \& Cooke 1876). In the beginning of the $20^{\text {th }}$ century, European mycologists continued to describe the genus from the region. For example, Hennings (1904) cited $C$. cibarius and also described the species $C$. helvelloides Henn. More recently, Singer et al. (1983) reported three taxa, C. atratus Corner, C. hystrix Corner and C. guyanensis Mont. and reported a yellow unknown chanterelle that resembles $C$. cibarius in neighboring Manaus, in the State of Amazonas.

Despite the reasonable frequency in which species of Cantharllus have been cited in Northern South America, it is now believed that the number of Cantharellus taxa in the Brazilian Amazon is smaller than otherwise cited, since many of these taxa have been transferred to other genera (see comments by
Wartchow et al. 2012).

At present, the only recognized species of Cantharellus from the Brazilian Amazon is C. guyanensis. The most recent citation of $C$. guyanensis was by Souza et al. (2008), who reported the production of protease by this species. In this article, we propose a new species of Cantharellus collected in 'terrafirme' forest in Amazon.

\section{Methods}

Cantharellus basidiomata were collected in an area of "terra-firme" forest 30 $\mathrm{km}$ from Manaus, near to a small farming town (Nogueira \& Mainbourg 2001). Microscopic observations were made from material mounted in $3 \% \mathrm{KOH}$ and Congo red solutions. Presentation of basidiospore data follows the methodology proposed by Tulloss et al. (1992), slightly modified by Wartchow (2012) and Wartchow et al. (2012). Measurements and statistics are based on 40 spores. Abbreviations include $\mathbf{L}(\mathbf{W})=$ average basidiospore length (width), $\mathrm{Q}=$ the length : width ratio range as determined from all measured basidiospores, and $\mathbf{Q}=$ the $\mathrm{Q}$ value averaged from all 


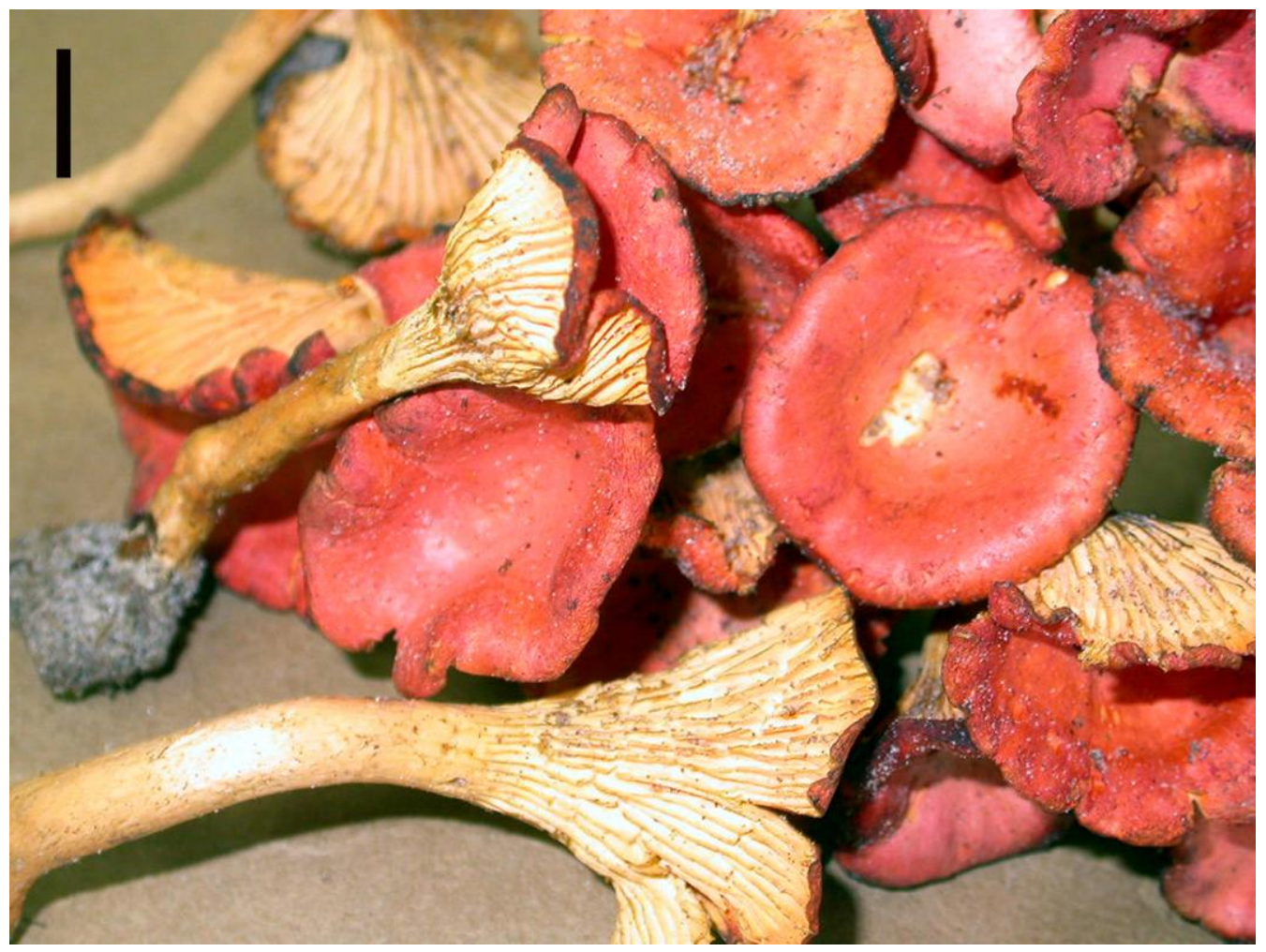

Fig. 1 - Basidiomata of Cantharellus amazonensis. Holotype. Scale bar $=10 \mathrm{~mm}$. Photo by Jucileuza C. Santos.

basidiospores measured. Colour codes are based on the Online Auction Color Chart (2004). The holotype is deposited at JPB (Thiers 2012).

\section{Results}

Cantharellus amazonensis Wartchow, sp. nov. MycoBank MB800535.

Figs 1-4

Etymology - pertaining to the Amazonia biome where the type was collected.

This species is characterized by the red pileus, yellow folds and stipe, nonanastomosed folds, basidiospore size (8.5-10.8 $\times 4.8-6.5 \mu \mathrm{m})$ and thin-walled ending elements of the pileipellis.

Holotype - BRAZIL. Amazonas, Manaus, Ramal Pau Rosa, BR-174, March 2007, J.C. Santos (JPB 46804).

Pileus ranging from $30-35 \mathrm{~mm}$ in diam., cyathiform to subinfundibuliform, bright red (OAC 495-496, 572) to somewhat slightly paling, mostly toward center; surface slightly fibrillose at margin, glabrescent, smooth in the rest; margin entire, sometimes lobed, slightly enrolled; context fleshy. Hymenophore decurrent, with folds appearing truly lamellate (about $2 \mathrm{~mm}$ broad), subcrowded, infrequently dichotomous, non-anastomosing, non-venose, yellowish (OAC 813-814) to pale orange (between OAC 763-764); edge entire, sharp. Stipe up to $60 \times 4 \mathrm{~mm}$, equal slightly expanding upward and subcylindric, more or less concolorous to folds (OAC 763-764) in few young specimens yellowish orange (OAC 763), slightly longitudinally fibrillose over entire length; context solid, remaining so in dried state. Odor very pleasant, like flowers. Taste not distinct.

Basidiospores 8.5-10.8(-13.7) $\times(4.3-$ )4.8-6.5(-7) $\mu \mathrm{m}, \mathbf{L}=9.7 \mu \mathrm{m} ; \mathbf{W}=5.5 \mu \mathrm{m}, \mathrm{Q}$ $=(1.41-) 1.48-2.10(-2.20), \quad \mathbf{Q}=1.76$, inamyloid, hyaline, ellipsoid to elongate sometimes cylindric, adaxial surface frequently concave, subreniform, thin-walled; hilar appendix prominent, obtuse, sublateral to subapical; contents as small gutules. Basidia 60-70 × 6.5-8.5 $\mu \mathrm{m}$, slender clavate, mostly with 6 sterigmata, each up to $5 \mu \mathrm{m}$ high. Basidioles plentiful, slender clavate. Subhymenium with slender branched hyphae about $5 \mu \mathrm{m}$ wide from which the basidia and basidioles arise. Cystidia absent. Pileipellis composed by plentiful cylindric hyphae 3.57.5 radially oriented then more or less 


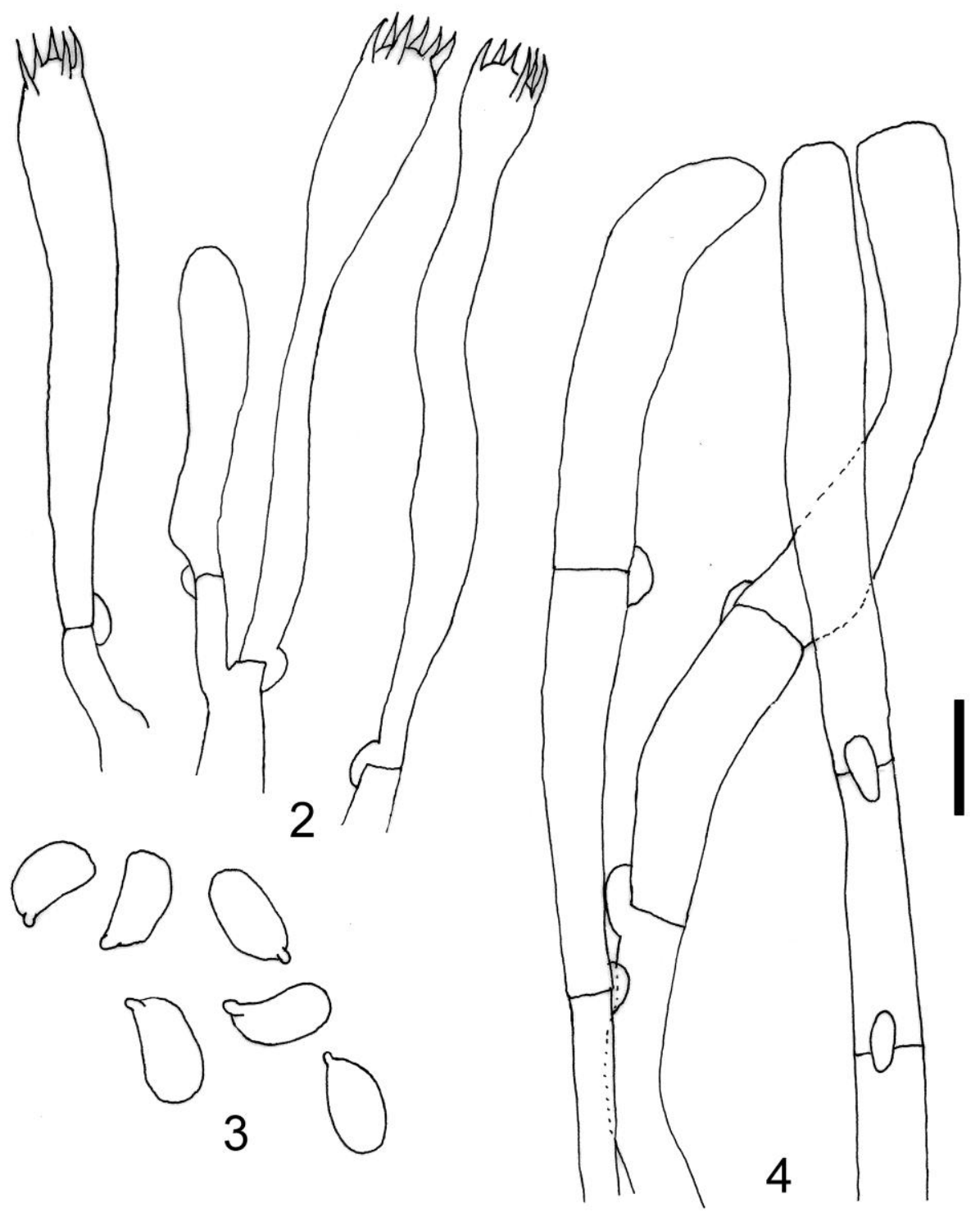

Figs 2-4 - Cantharellus amazonensis (holotype). 2. Basidia and basidiole. 3. Basidiospores. 4. Terminal elements of the pileipellis. Scale bar $=10 \mu \mathrm{m}$.

interwoven to suberect, frequently compressed, colorless or pale yellowish orange, thin-walled; the terminal cells measuring to $40-60 \mu \mathrm{m}$ long, cylindric, with mostly rounded obtuse apexes. Hymenophoral trama irregular, with abundant conspicuously interwoven hyphae up to 2-6 $\mu \mathrm{m}$ wide. Clamp connections proliferate, present on most septae. forest.

Habitat - gregarious on soil of Amazon

\section{Discussion}

Cantharellus amazonensis can be accommodated in the subgenus
Parvocantharellus Eyssart. \& Buyck, due the small size, thin-walled elements of the pileipellis and prolific clamp connections in all tissues (Eyssartier \& Buyck 2001). This new striking and uncommon species is easily characterized by the red pileus contrasting with the yellowish hymenial folds looking-like true lamellae and stipe and size of the basidiospores 8.5-10.8(-13.7) × (4.3-)4.8-6.5(-7) $\mu \mathrm{m}$. According to the key by Corner (1966), our species is in the group of chanterelles with red pileus and relatively dry surface.

This species is distinct from the reddish Cantharellus cinnabarinus (Schwein.) Schwein., that is known from Canada, USA and Trinidad. Cantharellus cinnabarinus can 
be easily distinguished in the field by its venose and concolorous folds to cinnabar-red or vermilion and discoloring orange pileus and concolorous stipe (Corner 1966). Petersen (1979), on the other hand, reported collections with less brightly coloured pileus. Microscopically this species differs from $C$. amazonensis in the smaller basidiospores $(6.46-) 6.71-7.57(-8.13) \times(3.75-) 3.82-4.68(-$ 5.21), $\mathbf{L}=7.14 \mu \mathrm{m} ; \mathbf{W}=4.25 \mu \mathrm{m}, \mathrm{Q}=(1.47-$ )1.57-1.80(-1.89), $\mathbf{Q}=1.69$ and variously thick-walled hyphal extremities of the pileipellis (Buyck et al. 2011). Corner (1966) reported it from Trinidad and Japan with somewhat wider basidiospores 6.5-7.5 × 5-5.7 $\mu \mathrm{m}$. More recently Pegler (1983) cited it from the Lesser Antilles, in the island of Martinique under Coccoloba uvifera, with thin walled hyphal extremities of the pileipellis and larger basidiospores $8-10 \times 4.7-6, \mathbf{L}=9 \mu \mathrm{m} ; \mathbf{W}=$ $5.3 \mu \mathrm{m}, \mathbf{Q}=1.68$, which probably represents a different taxon. Pilz et al. (2003) also used the epithet 'cinnabarinus' to describe collections made outside of North America (Japan, West Indies, and Central and South America for example). However, as discussed by Pegler (1983), all of these reports probably correspond to different taxa and need to be revised.

In tropical regions such as South Asia and Africa other reddish taxa occur. The Malaysian $C$. pudorinus Corner differs in the flesh-pink to apricot pileus and stipe, and shorter and proportionally wider basidiospores 7-9.5 × 6-7 $\mu \mathrm{m}$ (Corner 1966, Eyssartier et al. 2009). Cantharellus incarnatus Heinem. from Congo differs in the more robust basidiome, pink-orange folds and smaller basidiospores 7$7.8 \times 4-5 \mu \mathrm{m}$ (Heinemann 1958, 1966, Corner 1966). The other African red chanterelles $C$. floridulus Heinem., $C$. heinemannianus Eyssart. \& Buyck, C. symoensii Heinem. and C. platyphyllus Heinem. differ from the two taxa mentioned above and our new species, primarily in the lack of clamp connections in their tissue (Heinemann 1958, 1966, Corner 1966, Eyssartier \& Buyck 1998, Buyck et al. 2000). The two later taxa were recently separated as distinct genus Afrocantharellus (Eyssart. \& Buyck) Tibuhwa (Tibuhwa et al. (2012).

Cantharellus amazonensis is now the second taxon of this genus found in the Brazilian Amazonia after C. guyanensis. A third species of Cantharellus might be a yellow chanterelle similar to northern temperate $C$. cibarius Fr. s.l. described in earlier collections by Singer et al. (1983). However, this material needs to be recollected, examined and described using modern species concepts of the genus.

\section{Acknowledgements}

We thank Dr. Ron Petersen for suggestions regarding the identity of this Cantharellus, Dr. Andrew W. Wilson for reading pre-publication version and giving valuable suggestions, Dr. Leonor C. Maia, for authorized the use of the laboratory at Department of Mycology, Universidade Federal de Pernambuco, and FACEPE for a Post-doctoral grant to FW (BFP 0100-2.03/09).

\section{References}

Berkeley MJ. 1856 - Decades of Fungi LILIV: Rio Negro Fungi. Hooker's Journal of Botany and Kew Garden Miscellany 8, 129-144.

Berkeley MJ, Cooke MC. 1876 - Fungi of Brazil, including those collected by J.W.H. Trail, Esq., M.A, in 1874. Journal of the Linnean Society of London, Botany15, 363-398.

Buyck B, Eyssartier, Kivaisi A. 2000 Addition to the inventory of the genus Cantharellus (Basidiomycota, Cantharellaceae) in Tanzania. Nova Hedwigia 71, 491-502.

Buyck B, Cruaud C, Couloux, Hofstetter V. 2011 - Cantharellus texensis sp. nov. from Texas, a southern lookalike of $C$. cinnabarinus revealed by tef- 1 sequence data. Mycologia 103, 1037-1046 doi:10.3852/10-261

Corner EJH. 1966 - A monograph of Cantharelloid Fungi. Annals of Botany Memoir 2. Oxford University Press, Oxford.

Eyssartier G, Buyck B. 1998 - Contribution à la systématique du genre Cantharellus en Afrique tropicalle: études de quelques espèces rouges. Belgian Journal of Botany 131, 139-149.

Eyssartier G, Buyck B. 2001 - Note nomenclaturale et systématiaque sur le genre Cantharellus. Documents Mycologiques 31, 55-56.

Eyssartier G, Stubbe D, Walleyn R, Verbeken A. 2009 - New records of Cantharellus 
species (Basidiomycota, Cantharellaceae) from Malaysian dipterocarp rainforest. Fungal Diversity 36, 57-67.

Heinemann P. 1958 - Champignons recoltes au Congo Belge par Madame M. GoossensFontana. III. Cantharellinae. Bulletin du Jardin Botanique l'État Bruxelles 28, 385-438.

Heinemann P. 1966 - Cantharellinae du Katanga. Bulletin du Jardin Botanique l'État Bruxelles 36, 335-352.

Henkel TW, Aime MC, Chin MML, Miller SL, Vilgalys R, Smith ME. 2012 Ectomycorrhizal fungal diversity and discover of new taxa in Dicymbe monodominant forest of the Guiana Shield. Biodiversity and Conservation (in press).

Hennings P. 1904 - Fungi Amazonici I. a cl. Ernesto Ule collecti. Hedwigia 43, 154186.

Nogueira ACF, Mainbourg EMT. 2010 - A comunidade do Pau Rosa/Amazonas e a relação entre natureza e o processo saúde/doença. Saúde e Sociedade 19, $22-$ 34.

Online Auction Color. 2004 - The Online Auction Color Chart. Online Auction Color Co., Stanford.

Pegler DN. 1983 - Agaric flora of Lesser Antilles. Kew Bulletin Addiional Series 9, 1-668.

Petersen RH. 1979 - Notes on cantharelloid fungi. IX. Illustrations of new and poorly understood taxa. Nova Hedwigia 31, 123.

Pilz D, Norvell LL, Danell E, Molina R. 2003

- Ecology and management of commercially harvested chanterelle mushrooms. USDA General Technical Report, Portland.

Singer R, Araújo IJS, Ivory MH. 1983 - The ectotrophically mycorrhizal fungi of the neotropicall lowlands, especially Central Amazonia. Beihefte zur Nova Hedwigia 77, 1-339.

Souza HQ, Oliveira LA, Andrade JS. 2008 Seleção de Basidiomycetes da Amazônia para produção de enzimas de interesse biotecnológico. Ciência e Tecnologia de Alimentos 28 (suppl.), 1-9.

Thiers B. 2012 [continuously updated] - Index Herbariorum: A global directory of public herbaria and associated staff. New York Botanical Garden's Virtual Herbarium. http://sweetgum.nybg.org/ih/ Tibuhwa DD, Savic S, Tibell L, Kivaisi AK Afrocantharellus gen. stat. nov. is part of a rich diversity of African Cantharellaceae. IMA Fungus 3, 25-38.

Tulloss RE, Ovrebo CL, Halling RE. 1992 Studies on Amanita (Amanitaceae) from Andean Colombia. Memoirs of the New York Botanical Garden 66, 1-46.

Wartchow F. 2012 - Clavulina incrustata, a new species from Pernambuco, Brazil. Cryptogamie, Mycologie 33, 105-113.

Wartchow F, Buyck B, Maia LC. 2012 Cantharellus aurantioconspicuus (Cantharellales), a new species from Pernambuco, Brazil. Nova Hedwigia 94, 129-137.

Wilson AW, Aime MC, Dierks J, Mueller GM, Henkel TW. 2012 - Cantharellaceae of Guyana I: new species, combinations and distribution records of Craterellus and a synopsis of known taxa. Mycologia, in press. 